InVisible Culture • Issue 33: After Douglas Crimp

\title{
After Douglas Crimp \\ Questionnaire Response: \\ Rachel Haidu
}

\section{Rachel Haidu}

Published on: Jan 05, 2022

DOI: $10.47761 / 494 a 02 f 6.4 c 95889 c$

License: Creative Commons Attribution 4.0 International License (CC-BY 4.0). 


\section{Mourning and Proximity in a Bad Time}

The last time I spoke to Douglas it was the week of my birthday. I had a lot to tell him: not only about the birthday party I'd thrown for myself but the trip I was about to take, with a former student of his who'd been a distant friend for years. It was unusual to have so much to report; usually Douglas did most of the talking, and if I had a particularly entertaining story or gossip to relate, it came much later in the conversation. But those days he was mostly homebound and weak. He could report on who'd come to visit but the usual litany of dance performances, exhibits and gallery shows, dinners and outings was diminished. This time, my news took precedence and there was, for me-as there had been over the course of many months of his long and building illness-a sense of anxious anticipation about this.

Dying sucks a lot out of someone. Not only the energy to do things but the verve with which one reports those things. Douglas was a big reporter. How many mornings had I received emails telling me about what he'd done the night before? Litanies of what he'd seen or heard (dance, concerts) or, often in the midst of a weekend, what he'd seen in galleries and museums. This recounting was so paramount in our friendship that I began to sense it had its own double function: in one direction, certainly, towards friendship and intimacy; but what was the other? I am tempted to say it went towards the aesthetic experience itself. But recounting, I saw, didn't necessarily reflect or expand the thing itself. It didn't do the work that our work is supposed to do, as "critics." (He rejected the term art historian, and I thought that was fair, even if it undercut the ways he expanded the field of art history, its modes of writing, and the intermingling of politics, ethics, and aesthetics.) In fact, recounting what he'd seen or heard sometimes barely acknowledged the existence of critical work. Almost never did he email about something he was writing about (though sometimes he complained about the writing process itself; that was different). What was the nature of this recounting, then?

Chit-chat about or even deeply nit-picking a dancer's performance is a trope in itself, with its own history among balletomanes. 1 But there was something about the concision with which Douglas would recount-not going into any kind of depth or analysis of the performance or whatever he'd seen-that was striking. At most a performance might earn a descriptor ("I saw Yvonne's performances yesterdayamazing." "The show looks great." "Trifinov's is the best Chopin I've ever heard.") Full sentences, but nothing more. Was this recount-mode about "aesthetic experience"? Or 
was the form of the recounting important in itself, in its critical nothingness, its laconic brevity?

Like all communications of an intimate nature, Douglas's seemed to purport to shrink geographical distance. The notion of distances closing and opening got me to start to think, recently, about these emails in relation to a metaphor-homonym: the fan. One who adores; also, as Mallarmé writes, an instrument of "closed flight" and "space quivers." 2 Once upon a time and more recently in (to use a descriptor Douglas didn't like) campy performances, fans (in the form of handheld objects) have been used to shield/flirt, to cool/excite: to hold others' gazes while producing their blind spots. Like those emails that seek to make a connection: to connect, but not allow too much depth.

I should note that I rarely read these emails that reported on the previous night's events without suspecting that Douglas was cutting and pasting and sending the same account to different people. Our fan, I suspected-with a silent but somewhat excited assent, because I liked so much the other people I knew in his contacts-was not a secure nodal point between two people. The fan I imagined these emails creating was more like someone at a party who might be shielding something from one person in a kind of fictionally private moment but is in fact drawing an audience to witness that fiction of privacy. The audience, then, was a fiction of mine, as far as I knew: there was no circle of friends blind copied on the email, not that he said. Still, there was a sense of community lurking behind this semi-fiction of privacy. Most of my friends, when they email me something personal, write in depth about something: a set of feelings, a new argument with university administration. Not Douglas: these were short missives, brief accounts. Been there, saw that; now you know. The fan opens, and it closes.

Today, in an after-ness that is defined not only by the loss of a friend but by a pandemic that's taken both proximity and "live" aesthetic experience out of reach, I'm thinking about this a lot: the peculiar combination of proximity and distance, of adoration and seduction, that the metaphor of the fan enables. Friendship in proximity and seeing art "live." Both things, being impossible to reach in vivo, offer themselves to be considered now. Reflection with a side helping of mourning.

We often think of aesthetic experiences as aligned with our singularity, perhaps even limited by it. Aesthetic theory is one with ideologies of individuality and individualism: I teach this all the time. For some, categories of art forms array according to how well they lend themselves to "collective" experience. Easel painting is supposed to be a medium we contemplate in the singular; mural painting is supposed to be something 
we experience in the plural. TV is in the singular (or virtual collective); film produces what I learned in grad school as the once hardy and hopeful "simultaneous collective." I don't really believe in these characterizations of such now-hybrid categories anymore, and I know Douglas didn't. The apparently singular or individuated experience has ghosts of collectives and ancestors dancing around it; the collective can sometimes go so deep into your body that you feel your skin, your individuated container-hood, more sharply than ever. Thinking of Douglas, I have to ask: is it an accident that he was so in love with performance, and especially dance, towards the end of his life? Performance involves both the hyper-individuated pleasure of seeing something live and the proto-collective experience of seeing simultaneously. Collectivity and simultaneity might signal the majesty of a kind of loosely Marxist dogma, but the intense pleasure of the balletomane-one version of a fan--usually disdains such doctrines. Moreover, that level of intense pleasure is what those emails reified, in refusing the majesty of an argument, let alone one that had promissory political-economic weight. He didn't want to write more, both because he had to rush off to the next thing - such is the life of the adoring fan-and because the experience didn't need more.

On the other hand. The simple act of recounting puts a lot of stock in the agent or actor herself: think of the person holding the fan, perhaps fluttering it in front of their face or some other part of their body; think of the adulation the fan feels for the artist. The horizon of the collective recedes as one is addressed on one's own, by a singular person. Notions of proximity and distance allow the concepts that frame the notion of collectivity--solidarity, production, or alienation-to float away. We are just us two, and whether there are more or not, surrounding us, is not the point, in this moment of writing or reading.

Part of my problem with these emails was my problem. They felt a little sterile to me: I never really loved them wholly. I did like them: I liked reading what he was doing and seeing and hearing. Like our phone calls-dreaded, because since my 20s I haven't ever looked forward to a phone call; still, they were always great when I actually had them--Douglas's emails left me with two residues. One: envy. He saw so much. So much dance, so much performance, so much art, so much music. (Theater, once the precinct of the most valued experimentation merited not a single visit in fifteen yearsnot that I can remember.) I certainly saw things too but unless we were seeing things together, they were often things he didn't see-international art exhibitions, for 
example. They would end up feeling hollow. (His patterns felt more valuable than mine.)

Then, there was the issue of dinner. When I first moved to Rochester in 2003, I went with him to everything in this town that was new to me, old to him. Films, sushi. Night after night, we went to the same sushi place, and each new sequence of director-based series at the Dryden, the cinemathèque associated with the George Eastman House (now, George Eastman Museum). That's how I saw all the Fassbinder, Ozu, and Pasolini I've seen. It was like getting a crash course in Douglas's aesthetics: transgression and hiddenness, Japan. That summed it up, or seemed to, then. But a few years of this passed: I met my now ex-partner and had a child. After the birth of my kid, sometimes I just wanted to have dinner. Often, with Douglas. In New York together we continued our old patterns of seeing art, including performances, and then having a meal. But in Rochester, I could only invite him over, cook for him, listen to him. I did it over and over, but always missed our old patterns. Films, sushi: I missed that. A case of privation generating more privation. What I was missing was especially that free form of seeing that was untethered from "work," from criticism and so on; seeing things because that's what you do the moment you have some free hours.

In his last few years, while he was finishing his memoir, his essays and articles tended not to lead towards theses, as much of his earlier work had done. Or, more precisely: the sense of a thesis depended on the reader and how she read. He would laugh a little, bemused and flattered, that I had retrieved an actual thesis from my favorite chapter of Before Pictures, the whole of which is a complex dismantling of expectations from both criticism and memoir. What he was doing in his new writing was describing experiences, often at the cost of what we would call "critique." Throughout especially his essays on dance, he sets forth a different model for writing about or through art, Sedgwickian in its reparative effort, its withdrawal from the idealization of the radical, the regime of the redemptive or the new. $\underline{3}$ This other model owes everything to performance and to community-the twin poles that had been born in his friendships with Craig Owens and his participation in ACT UP. It enables the new kinds of description that populate Before Pictures and lends all of his recent writing not only a kind of stylistic restraint and elegance but an argument with polemicism itself. Douglas was not himself anti-polemical. In fact, he was furious, much of the time, at how things were going. But as a writer, and perhaps a looker, he was testing what could be said when the paranoid drivers of polemicism are shut off. 
I want to retrieve these essays and emailed reports-different as those two categories are-at a different level, at the level of the self that is entailed by criticism. After all, idealization is not just about the work of criticism: it is about setting oneself apart from experience. Sedgwick's notion of reparative writing originates in the claim that "any theory, to be a theory...requires or produces figure/ground relations"; to this dilemma she prescribes "a reparative impulse...[that] wants to assemble and confer plenitude on an object that will then have resources to offer to an inchoate self." $\underline{4}$ If reparative criticism has become its own pseudo-norm, its attention to the role of paranoia itself, as a norm-setting instinct, can get too easily lost. Was she telling us what to (try to) do? Certainly. Was she also trying to get us to understand the role of a master theory? Indeed. But what is the relation between this "inchoate self" and the selves writing and looking? It could be argued that there is a kind of elision between those states inside Sedgwick's brilliant essay, as if the experience of plenitude were an ongoing, near-stable state that can always be tapped into or sought, as if the selves that watch or look or listen (or all of the above) and those writing channeled directly amongst themselves. What reporting does, in the regime I've been describing, is to mark a kind of boundary between the pleasures of looking/watching/listening and their own rather sterile pleasures-if pleasure is even the right term. Those emails tested the openness that reparative writing relies on, or elicits.

Jacques Derrida, another writer who had unquestionable value for Douglas at one point, questions the distinction between the outsideness of "that which affects me" and the "me" that is served by or affected by things beyond me. The difference between "onanism" and writing, as he puts it, is difficult to discern (though his use of various metaphorical phrases-I am about to quote one-to summon the sexual-reproductive suggest that his address of that difficulty will be normative): "The worldly residence of a signifier becomes impregnable. That which is written remains, and the experience of touching-touched admits the world as a third party. The exteriority of space is irreducible there." $\underline{5}$ This is Derrida's description of what he calls "auto-affection." Sedgwick comes at the problem by questioning theory itself, what it takes "to be a theory." Derrida reinscribes the problem of subject-object relationships onto the question of how the self relates to the experience of exteriority. In his address of that experience, it's clear that the relation to an outside object (signifier) is identical to that relation one builds to oneself, also to others: "Only a being capable of symbolizing, that is to say of auto-affecting, may let itself be affected by the other in general. Autoaffection is the condition of an experience in general." $\underline{6}$ 
Douglas is not just at the nexus between these two writers (who themselves served as two moments in his personal evolution as a critic); he was actively trying to do something with his life that responded to their work. On the one hand, DerrideanLacanian psychoanalytic and poststructuralist thought, translated by the October preoccupation with art and aesthetic experience, promises to undo the static nature of binary thought (for example: me versus it, me versus you, subject versus object). Douglas had responded to that set of promised undoings in his writing by the time he left the magazine (witness, among others, the sensitive form of institutional critique that he devised to complicate that binary and its residence inside institutions, which is to say, inside pleasures, which led him away from such "critical" questions altogether, in certain ways). Then, in the years following, during his continued activism, that always-undoing binarism met the confrontational, polemical, militant-but-complex conceptions of self and community that moved him past "Pictures" and in most ways past art history. ACT UP allowed and was all of that, plus a reminder that art can migrate past one set of ideas to another: there isn't a final resting place, no matter how persuasive a set of artworks might be.

But also, as Before Pictures describes, to move past is always to return to that past place. There was no Pictures "moment" without the glee of disco and sex with friends and strangers, without Charles James and a weird but lucky job at the Guggenheim. There would be no end to the AIDS crisis, then or now, not only because it goes on (demographically, in lives being lost) but because of how our lives are ghosted by its dead, and explicitly threatened by the ways that concepts of individual and Christian rights continue to be deployed. The argument that history lives in the present is one that would seem to set the present into a kind of parametric status, holding a sense of experience beyond what is sensible at that moment, reminding us of the porousness of that "first-hand" reality. And yet: that is not all of how we experience histories-in-themaking. Porousness, then-as-now: yes. But also, the 'right now' can seem to appear very much in-itself, as the existence and grammar of ACT-UP testify to.

Maybe it's worth also repeating one of the key distinctions that Douglas himself made, between the work (as object of criticism) and "experience": "An evening of dance is what takes place in a theater-a single dance or a program of dances, each selfcontained.... An event, by contrast, is not a work: it is an accumulation of fragments that are impossible to see as an entity-not a dance but dancing." 7 This emphasis on experience, on "not a dance but dancing," seems to beg a further question. What are we describing when the "thing" itself becomes irreducible, not a thing but an ongoing 
experience, one that refuses the finitude of the object? Douglas answered this in detail with what he saw: "Their allegro trio became the very image of spring, the dance equivalent of the grove of flowering crab apple trees that were the first thing you saw walking from the Beacon train station as you headed downhill towards the museum." Could anyone mistake that as prescriptive, let alone critical narration, the instrumentalization of experience as thingness? $\underline{8}$ In a strong sense, he was working to sever what critics do from the notion of a "critical model," an explanatory hypothesis (like what we look for in Marx, etc.). Adjusting his writing so that it would derive, stylistically and in terms of what it wanted to do, from what he observed as intrinsic to Cunningham and to so much of the modern art that he loved was where Douglas landed, methodologically. This is what he got to by looking at art and describing it in critical spaces. In other words, his writing was a lesson learned, not just invented, and that was one of the things he was saying in that article on the Cunningham "events." There was, in so much art as in so much of Douglas's writing, a kind of irreducible indifference to what a reader (or anyone else) feels or thinks. That lack of a desire to please, to persuade or otherwise seduce is what used to be called "modernism." He was -like so many of the artists before him and still-making it not only exciting, but a kind of model for life. Writing and observing as "auto-affection," trying not to displace the wish for approval onto the other reader, trying not to instrumentalize that moment in which one reaches out to touch and be touched.

In a brilliant essay on fans, women, and friendship, Laura Burch writes about a $17^{\text {th }}$ century French heroine who decides, after a ruined marriage, to seek a best friend. Her friends warn her against this project and "when her experience finally forces her to admit the truth of her friend's advice...Belinde revises her original positions on pleasure and living for oneself." $\underline{9}$ Acknowledging that "the greatest joy of friendship lies in exclusivity and distinction," she decides to release herself from the passion of friendship and instead, becoming "agreeable to everyone," allows pleasure to be "communally shared rather than individually enjoyed. Belinde herself has in effect given up on the pursuit of personal pleasure derived from others inherent in the search for perfect love." And by the same token, perhaps surprisingly, she uses this "selfregulation" to "lead, not to the heart, but to the mind, the capacity to judge. Keeping her own sources of pleasure to herself, discovering pleasure in living for oneself, Belinde the satirist thus becomes, paradoxically, the point around which people congregate to learn more about themselves." $\underline{10}$

Douglas was devoted both to the pursuit of friendship and to disinvesting in idealisms, especially idealized forms of love. Was the issue (for me) with these emails that they 
were modes of "keeping sources of pleasure" to himself, in a manner that paradoxically sharpened his capacity to judge, even to invent and model new forms of criticism, perhaps of citizenship in a world of art and performance? I think that is completely right. Not that friends or friendship were instrumentalized in his devotion to criticism, nor that he was practicing a form of ascetic friendship, too diffused to be real or intimate. The possibility of friendship, even friendship-love, without the idealisms that love (romantic or otherwise) so often depends on, could open up a space for the kind of restraint that would also nurture critical judgment. Perhaps these kinds of love would also open up other kinds of love. What is the difference between love and critical judgment, once one has turned those "paranoid drivers" off?

Douglas's critical judgments began to live in a lapidary voice, a voice putting all of its efforts into not redirecting the work towards an objective, towards a push for extracted meaning. It is worth noting that that lapidary voice is an instrument on which he worked very hard. There might not be any form of language that doesn't argue for its own virtues, but his did so by paring back, not elaborating, and by bringing the reader over to his side only subtly, and only if the reader was patient enough. Like the emails, this lapidary voice shared. But wasn't it precisely the sharing itself that I found frustrating, to the degree that it also marked a lacuna in my own experience, one that in the end only spoke to distance, irresolvable and unacknowledged? Didn't I actually want more: more voice, more description, more said? Distance, touch/touching, all of it getting acknowledged and perhaps woven into the text?

His emails, I was saying, functioned to "fan" out. Even if one saw their author understanding an object as an "experience" and not a "work," they reported on a thing that happened. In other words, they depend on the signifier being exterior to the self writing: and in that dependency, no matter how important the work of writing itself, there is something vital, in the sense of being alive. To email about a performance without narrating it too much, without putting it into a model or indeed into any kind of perspective at all, was to witness the intractability of distance. That distance was-is -between the author and the work she's looking at. But the emails went a step further, asking us to see that intractability from a close point. I guess that's what felt like the intimacy in those emails. Writing from up close, but without closing that secondary distance, between us, without telling me enough so that I too might see what he was seeing. 
One of the reasons I wanted to write about Douglas's emails is that they posited themselves as nothing more than a communication between two points. Not a new form of writing or a new form of reading or a new form of solidarity, criticism, or anything else. They struck me as odd, but not declaratively so, not "interestingly" so, at least not until their author was gone. Mourning, as we know, does something to the thing that one took for granted. I find that in thinking of others I have lost lately that my mind goes to the things which I didn't know were so immanent to my sense of that person until they themselves-the person, the things-were gone. The trip from the other subway station-not the one that I had used to visit my father for almost a decade, but the one that I discovered only while I was caring for him when he was sick. Mourning my friend, it's not just the emails that I miss, nor their routine nature, nor even the way that they made me a little crazy, back then. It's the naïveté of thinking that there is nothing to think about here. "Move along; nothing to see here." That index of ideology is also the index of life as we lived it before-whatever the event that "before" refers to. It's a shock, especially when you can't help mentally going back to these indices of normality. The normalities that make up intimacy, that is.

"Mourning and Militancy" also had a before, and like Before Pictures, it was one that had no self-awareness, no self-consciousness until it was too late. We are in another of those belated moments now, and the "we" I refer to has no bounds, even though it has its exceptional victims, the ones who are really in it. I've been thinking about that and how much Douglas would have hated this moment, this extended (forever?) pandemic. It's the ambiguity of this universal anguish with its layers of intensity striating a population: cutting the mourners off from one another; quieting the world even as it amps up misery, slicing and dicing audiences until there are almost none left. This moment coalesces everything that's wrong with the faux-universalisms that never appealed to him anyway, and also everything that's wrong with how we were already relating to one another.

I don't want to write about how to get anything back, and not only because that would be both inconceivable/impracticable and alien to the act of mourning. I want to note the loss to how we write and read-or how we could have been writing to one another, even back when we had the access to experience, to performances, and to promiscuity. I want to note it, because it is already time to rethink again how we do writing with respect to performances, intimacy with readers we know well and those we don't know at all. Inside of writing is a relation to history as it is taking place-even if it's a relationship we barely understand. How can we not reproduce the old ways of writing- 
after all, they were also old ways of living; how can we write to one another, differently?

Rachel Haidu is the author of two books, The Absence of Work: Marcel Broodthaers 1964-1976 (MIT Press/October Books in 2010) and Each One Another: The Self in Contemporary Art (University of Chicago Press, 2022).

$\underline{\text { Click here to return to the other questionnaire responses. }}$

\section{Footnotes}

1. Craig Owens, who is the friend who introduced Douglas to ballet, couldn't resist that kind of nitpicking in his one published work on dance, an uncharacteristically short piece on Coppélia as staged by George Balanchine in 1976: "As Swanilda, Patricia McBride seems totally unaware of these distinctions; while she charms throughout, her witty impersonation of the automaton is not allowed to move us: that is reserved for the great nuptial pas de deux which climaxes the Act III celebration." Craig Owens, "Politics of Coppélia," in Beyond Recognition: Representation, Power, and Culture (Berkeley, Los Angeles, London: University of California Press, 1992), 241.

2. According to the OED, "fanatic" is "such as might result from possession by a deity or demon" whereas its diminutive is just "a keen and regular spectator of a (professional) sport, orig. of baseball." Of course, there is nothing in this discrepancy but falsehood: that of sport as the only category of fan that approaches fanaticism, and the idea that demonic possession doesn't describe fandom. But everyone knows these things. "fan, n.2". OED Online. March 2020. Oxford University Press. https://www-oed-com.ezp.lib.rochester.edu/view/Entry/68000? $\underline{\text { rskey}=U M 5} \mathrm{~g} 2 \mathrm{w} \&$ result $=2$ (accessed June 01, 2020). Stephane Mallarmé, "Another Fan (of Mademoiselle Mallarmé's)" translated by A. S. Kline. See the Poetry in Translation

website: https://www.poetryintranslation.com/PITBR/French/Mallarme.php\# oc223495084. Accessed June 1, 2020. Others of Mallarmé's "fan” poems were dedicated to for example Méry Laurent, the courtesan who not only counted Mallarmé (and others including Manet-also her lover-and Proust and Whistler) among her "fans" but held her own salons, themselves precisely the kinds of events, mixing fashion and aesthetics, the diffuse company of friends and the imagination of intimacy. $\uplus$ 
3. This is not to say that these writings do not have a point, or even an argument. Sometimes the argument is crystalline: take the single-sentence climax of the liner notes he produced for the DVD of Merce Cunningham Dance Company's Park Avenue Armory Event (see note 9, below); contrast this with his parallel piece for Artforum, describing in remarkable and precise detail the events staged by the same company at Dia, in Hudson, NY: "Merce Cunningham: Dancers, Artworks, and People in the Galleries," Artforum October 2008 Vol 47, No. 2.

4. Eve Kosofsky Sedgwick, Touching, Feeling: Affect, Pedagogy, Performativity (Durham and London: Duke University Press, 2003), 116; 149.

5. Jacques Derrida, Of Grammatology [1967], trans. Gayatri Chakravorty Spivak (Baltimore: Johns Hopkins University Press, 1976), 165. Auto-affection is the larger category into which the question of the interior monologue fits, as the irruption of a signifier (the word one hears oneself speak in one's head, talking to oneself) seemingly without an "exterior" prompt. Ibid, 98.

6. In 2004, Derrida would begin to answer the questions posed in his essay "Lanimal que donc je suis" (2002), proposing the "animal-other...a place of alterity that is radical enough to break with every identification of an image of self, with every fellow living creature, and so with every fraternity or human proximity, with all humanity." See Jacques Derrida, "And Say the Animal Responded?," trans. David Wills, in Zoontologies: The Question of the Animal, ed. Cary Wolfe (Minneapolis: University of Minnesota Press, 2004), 134. "Others," in other words, should not be heard as a category (e.g. other humans), but rather as naming a state in contrast to which one faces one's "own" otherness to oneself. $\leftrightarrows$

7. Douglas Crimp, “The Park Avenue Armory Event,” Artpix (DVD liner note), 2012.

8. Douglas Crimp, "Merce Cunningham: Dancers, Artworks, and People in the Galleries," Artforum, Vol. 47, No. 2. October 2008.

9. Laura Burch, "New Pleasure in Life Unfolding: Madeleine de Scudéry's Friendship Fan," Seventeenth-Century French Studies, Vol. 35, No. 1, June 1014, 10. The heroine of "Histoire de Belinde," is the "only one known Friendship Story (Histoire d'amitié)" amid the infinite number of love stories, in the assertion of Timande, a character in Madame de Scudéry's Conversations (1680-1692). Ibid, 8. Many thanks to Anna Rosensweig for her suggestion of this article. $\subseteq$

10. Burch, "New Pleasure in Life Unfolding," 11. 